\title{
PENGARUH TEKNIK TAKALINTAR TERHADAP KEMAMPUAN PROSES KOGNITIF SISWA SEKOLAH DASAR
}

\author{
Fery Muhamad Firdaus \\ Syarif Hidayatullah State Islamic University Jakarta \\ Jl. Ir. H. Djuanda No.95, Cemp. Putih, Ciputat, Kota Tangerang Selatan, 15412, Indonesia \\ fery.firdaus@uinjkt.ac.id
}

Artikel diterima: 29 Juli 2018, direvisi: 22 September 2018, diterbitkan: 30 September 2018

\begin{abstract}
Abstrak
Penelitian ini dilatarbelakangi dari masalah rendahnya kemampuan proses kognitif siswa pada konsep perkalian. Tujuan penelitian adalah untuk mengetahui pengaruh teknik takalintarterhadap kemampuan proses kognitif pada konsep perkalian di sekolah dasar. Penelitian dilakukan pada siswa kelas III semester 1 tahun akademik 2017-2018 di Sekolah Dasar Negeri Nangela sebagai kelompok eksperimen, dan di Sekolah Dasar Negeri Cipaku 03 sebagai kelompok kontrol. Sampel penelitian yaitu 20 siswa dari masing-masing kelompok. Selama proses penelitian, kelompok eksperimen diberikan teknik takalintar, sedangkan kelompok kontrol diberikan pembelajaran konvensional. Pendekatan penelitian yang digunakan yaitu pendekatan kuantitatif dengan metode eksperimen kuasi desain Two Group Randomized Subject Posttest Only. Analisis data dilakukan dengan uji-t. Tingkat signifikansi 0,05. Hasil penelitian menunjukkan perbedaan yang signifikan antara skor kemampuan proses kognitif siswa dari kelompok eksperimen dan kelompok kontrol. Hasil uji effect sizemenunjukkan nilai sebesar 0,892, dengan interpretasi termasuk pengaruh yang tinggi. Sehingga dapat disimpulkan bahwa teknik takalintar memberikan pengaruh tinggi terhadap kemampuan proses kognitif siswa pada konsep perkalian. Oleh karena itu, teknik takalintardapat menjadi alternatif pembelajaran yang dapat diterapkan dalam upaya meningkatkan kemampuan proses kognitif siswa sekolah dasar.

Kata Kunci: Teknik Takalintar, Kemampuan Proses Kognitif Siswa, Konsep Perkalian
\end{abstract}

\begin{abstract}
The Effect of Takalintar Technique on Cognitive Processes Ability of Elementary School Students)

This research is motivated from the problem of the low ability of students' cognitive processes on multiplication concepts. The aim of the study was to determine the effect of intelligent techniques on the ability of cognitive processes on the concept of multiplication in elementary schools. The study was conducted on third grade students of semester 1 of the 2017-2018 academic year in Nangela State Elementary School as an experimental group, and in Cipaku State Elementary School 03 as a control group. Research samples were 20 students from each group. During the research process, the experimental group was given takalintar techniques, while the control group was given conventional learning. The research approach used is a quantitative approach with the Two Group Randomized Subject Posttest Only quasi design experimental method. Data analysis was carried out by t-test. 0.05 significance level. The results showed a significant difference between students' cognitive process ability scores from the experimental group and the control group. The effect size test results show a value of 0.892, with interpretation including high influence. So it can be concluded that the takalintar technique has a high influence on the ability of students' cognitive processes on multiplication concepts. Therefore, takalintar technique can be an alternative learning that can be applied in an effort to improve the cognitive processing abilities of elementary school students.

Keywords: Takalintar Technique, Students' Cognitive Process Ability, Multiplication Concept.
\end{abstract}




\section{Pendahuluan}

Pendidikan merupakan suatu proses terencana yang bertujuan untuk membantu siswa melakukan perubahan yang lebih baik dari aspek kognitif, afektif dan psikomotor. Dari aspek kognitif, siswa mengalami perubahan dari yang tidak tahu menjadi tahu. Pada aspek afektif, siswa mengalami perubahan dari yang tidak baik menjadi baik, sedangkan dari aspek psikomotor, siswa mengalami perubahan dari yang tidak bisa menjadi bisa.

Kemampuan proses kognitif merupakan suatu kemampuan siswa dalam melakukan proses kegiatan berpikir dan bernalar dalam memecahkan suatu masalah. Kemampuan proses kognitif sangatlah penting dalam kegiatan pembelajaran, karena dengan kemampuan proses kognitif, siswa dapat memiliki pengetahuan, memahami, menerapkan, menganalisis, serta menciptakan berbagai konsep yang dibahas.

Salah satu konsep yang dibahas dalam pembelajaran di sekolah dasar yaitu konsep perkalian. Konsep perkalian mulai dibelajarkan kepada siswa sejak kelas dua sampai kelas tiga sekolah dasar. Berdasarkan hasil studi pendahuluan, diperoleh rendahnya kemampuan proses kognitif siswa kelas III SDN Nangela Kecamatan Paseh Kabupaten Bandung pada konsep perkalian. Rendahnya kemampuan proses kognitif siswa ditandai dari berbagai berikut ini: (1). Siswa tidak mahir dalam menjelaskan konsep perkalian sebagai penjumlahan berulang,
(2). Siswa tidak mahir dalam melakukan konsep perkalian, serta (3). Siswa tidak mahir dalam menyelesaikan permasalahan yang berkaitan dengan konsep perkalian.

Rendahnya kemampuan proses kognitif siswa pada konsep perkalian di kelas III sekolah dasar ini sangatlah disayangkan. Hal tersebut dikarenakan konsep perkalian merupakan salah satu dasar dalam kemampuan siswa belajar matematika. Konsep perkalian saangatlah menentukan sebagai dasar untuk pembelajaran matematika selanjutnya, seperti konsep KPK (kelipatan persekutuan terkecil), konsep pecahan, konsep geometri, serta konsep-konsep lainnya.

Berdasarkan pemaparan tersebut, alangkah baiknya manakala permasalahan rendahnya kemampuan proses kognitif siswa pada konsep perkalian segera diselesaikan. Salah satu cara dalam menyelesaikan permasalahan tersebut yaitu dengan menerapkan berbagai teknik dalam melakukan dan menyelesaikan masalah yang berkaitan dengan konsep perkalian, seperti teknik takalintar.

Rumusan masalah yang dikembangkan pada penelitian ini yaitu "Apakah teknik takalintar berpengaruh terhadap kemampuan proses kognitif siswa pada konsep perkalian?". Berdasarkan rumusan masalah tersebut, maka tujuan penelitian yaitu untuk mengetahui pengaruh teknik takalintar terhadap kemampuan proses kognitif siswa pada konsep perkalian.

Teknik takalintar merupakan singkatan dari tabel perkalian pintar. Teknik ini merupakan alternatif lain dalam 
melakukan dan menyelesaikan masalah yang berkaitan dengan konsep perkalian selain teknik bersusun pendek dan teknik bersusun panjang. Teknik takalintar, merupakan inovasi yang berkembang dari batang napier. Batang napier, ditemukan oleh seorang bangsawan dari Skotlandia John Napier. Alat perhitungan sederhana berikut ini banyak digunakan pada tahun 1600-an. Alat perhitungan ini dirancang untuk menyederhanakan tugas berat dalam perkalian (Sobel, dkk, 2002: 108).

Berikut ini cara menyelesaikan perkalian melalui teknik takalintar, diantaranya:

1. Buatlah sebuah tabel seperti dibawahn ini.

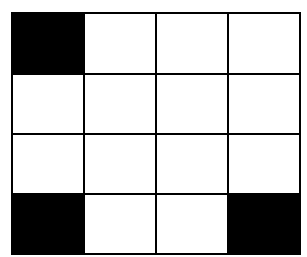

2. Setelah itu buatlah garis diagonal pada daerah pengerjaan.

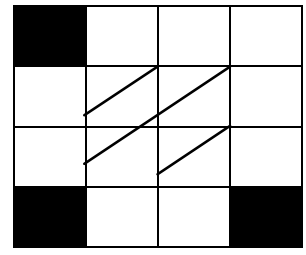

3. Lalu buatlah lambang perkalian $(x)$ pada kolom atas sebelah kanan.

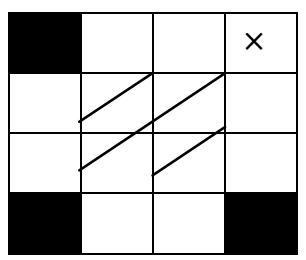

4. Setelah itu tulislah angka yang di inginkan pada kolom atas dan kanan. Contoh: $23 \times 40$

\begin{tabular}{|l|l|l|}
\hline 2 & 3 & $x$ \\
\hline
\end{tabular}

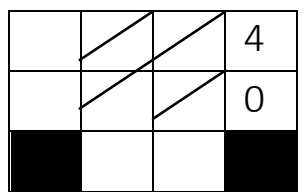

5. Lalu kerjakanlah dimulai dari $2 \times 4,2 \times$ $0,3 \times 4,3 \times 0$. Setelah hasilnya diketahui masukan pada kolom yang bergaris diagonal.

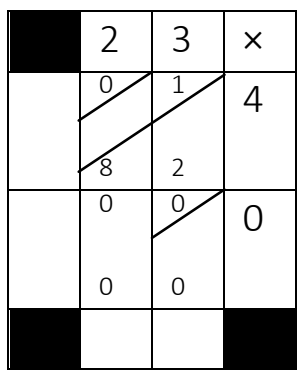

Tulislah hasil puluhan pada kolom diagonal atas dan satuan pada kolom diagonal yang bawah.

6. Setelah daerah pengerjaan sudah dikerjakan semua, jumlahkan hasil tersebut dengan cara menjumlahkan angkanya mengikuti garis/kolom yang sejajar sama dengan angka tersebut.

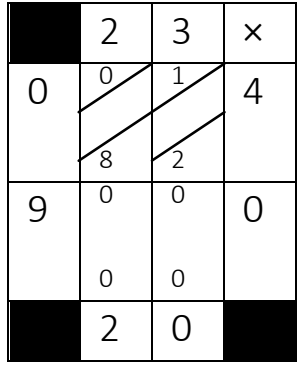

7. Cara yang terakhir yaitu, untuk mengetahui hasil akhirnya dilihat dari kolom sebelah kiri yaitu 0920, karena angka nol (0) tidak termasuk dalam hasilnya jadi hanya dituliskan 920. Hasil perkalian dari $23 \times 40=920$.

Kompetensi siswa yang diharapkan dalam penerapan teknik takalintar ini yaitu kemampuan proses kognitif. Kemampuan proses kognitif merupakan kemampuan 
siswa dalam melakukan proses kegiatan berpikir dan bernalar dalam memecahkan suatu masalah. Proses kognitif terdapat pada dimensi pengetahuan yang terdiri dari konsep dan pemahaman. Berikut adalah Taksonomi Bloom mengenai kemampuan proses kognitif yang telah direvisi Anderson \& Krathwohl (2001:6688) yakni: mengingat (remember), memahami (understand), menerapkan (apply), menganalisis (analyze), mengevaluasi (evaluate), dan menciptakan (create).

1. Mengingat (Remember)

Mengingat yaitu kemampuan seseorang untuk mengingat-ingat kembali (recall) atau mengenali kembali tentang nama, istilah, ide, gejala, rumus-rumus dan sebagainya, tanpa mengharapkan kemampuan untuk menggunakannya. Pengetahuan atau ingatan ini merupakan proses berpikir yang paling rendah.

2. Memahami (Understand)

Memahami yaitu kemampuan seseorang untuk mengerti atau memahami sesuatu setelah sesuatu itu diketahui dan diingat. Dengan kata lain, memahami adalah mengetahui tentang sesuatu dan dapat melihatnya dari berbagai segi. Seorang peserta didik dikatakan memahami sesuatu apabila ia dapat memberikan penjelasan atau memberi uraian yang lebih rinci tentang hal itu dengan menggunakan kata-katanya sendiri. Pemahaman merupakan jenjang kemampuan berpikir yang setingkat lebih tinggi dari ingatan atau hafalan.

3. Menerapkan (Apply)

Menerapkan yaitu kesanggupan seseorang untuk menerapkan atau menggunakan ide-ide umum, tata cara ataupun metode-metode, prinsip-prinsip, rumus-rumus, teoriteori dan sebagainya, dalam situasi yang baru dan konkret. Aplikasi atau penerapan ini adalah merupakan proses berpikir setingkat lebih tinggi dari pemahaman.

4. Menganalisis (Analyze)

Menganalis yaitu mencakup kemampuan untuk merinci suatu kesatuan kedalam bagian-bagian sehingga struktur keseluruhan atau organisasinya dapat dipahami dengan baik.

5. Mengevaluasi (Evaluate)

Penilaian atau evaluasi merupakan kemampuan seseorang untuk membuat pertimbangan terhadap suatu situasi, nilai, atau ide, misalnya jika seseorang dihadapkan pada beberapa pilihan, maka ia akan mampu memilih satu pilihan yang terbaik, sesuai dengan patokan atau kriteria yang ada.

6. Menciptakan (Create)

Merupakan jenjang berpikir yang mengarah pada proses kognitif meletakkan unsur-unsur secara bersama-sama untuk membentuk kesatuan yang koheren dan mengarahkan siswa untuk Mosharafa: Jumal Pendidikan Matematika Volume 7, Nomor 3, September 2018 Copyright $\odot 2018$ Mosharafa: Jurnal Pendidikan Matematika 
menghasilkan suatu produk baru dengan

mengorganisasikan

kemampuan siswa untuk

menciptakan. Menciptakan di sini mengarahkan siswa untuk dapat melaksanakan dan menghasilkan karya yang dapat dibuat oleh semua siswa

\section{Metode}

Pendekatan penelitian yang digunakan yaitu pendekatan kuantitatif, hal tersebut dikarenakan penelitian ini mengontrol bagaimana kelompok subjek penelitian diperlakukan dan kemudian mengukur bagaimana tindakan mempengaruhi setiap kelompok, sehingga diperlukan penelitian kuantitatif.

Metode yang digunakan dalam penelitian ini adalah eksperimen kuasi, hal ini dikarenakan penelitian dilaksanakan dengan maksud untuk mempelajari sesuatu dengan mengubah suatu kondisi dan mengamati pengaruhnya terhadap hal lain. Penelitianeksperimen kuasi yang akan dilaksanakan yaitu dengan bentukTwo Group Randomized Subject Posttest Onlydesign yang mengacu kepada pendapat Fraenkel\& Wallen (2007:278).

Yang menjadi populasi dari penelitian ini adalah seluruh siswa kelas III SDN Nangela dan SDN Cipaku 03 Kecamatan Paseh Kabupaten Bandung. Setiap masingmasing kelas diambil jumlah siswa yang sama sebagai sampel, yaitu sebanyak 20 siswa. Penempatan kelompok sampel pada kelompok eksperimen dan kelompok

Mosharafa: Jumal Pendidikan Matematika

Volume 7, Nomor 3, September 2018

Copyright @ 2018 Mosharafa: Jurnal Pendidikan Matematika kontrol dilakukan secara random atau acak.

Instrumen penelitian yang digunakan yaitu lembar tes kemampuan proses kognitif siswa pada konsep perkalian. Kegiatan evaluasi tes kemampuan proses kognitif siswa dilakukan dalam rangka mengetahui dan mengidentifikasi kemampuan proses kognitif siswa mengenai bahan ajar yang sedang dibelajarkan, dimana pelaksanaan evaluasi dalam penelitian ini bertujuan untuk mengukur kemampuan proses kognitif siswa mengenai materi perkalian. Pengembangan instrumen dilakukan dengan cara pengujian validitas, pengujian reliabilitas, perhitungan daya pembeda dan perhitungan taraf kesukaran.

Analisis data hasil tes dimaksudkan untuk mengetahui pengaruh teknik takalintardalam meningkatkan kemampuan proses kognitif siswa kelas III sekolah dasar mengenai konsep perkalian. Teknik analisis data yang digunakan pada penelitian ini yaitu teknik statistik inferensial parameter, di mana teknik ini dilaksanakan dengan menggunakan uji $t$, taraf signifikansi 0,05.

Penelitian dengan menggunakan metode quasi experimental designbentuk Two Group Randomized Subject Posttest Onlyini dilaksanakan dengan prosedur pelaksanaan penelitian sebagai berikut: Pertama, perencanaan dan persiapan penelitian, dimana pada proses ini dimulai dengan mendefinisikan masalah penelitian, mencari bahan rujukan, dan membuat hipotesis penelitian, 449 
http://journal.institutpendidikan.ac.id/index.php/mosharafa

menentukan desain penelitian, kemudian memilih sampel dari populasi dengan teknik mengocok kelompok sampel siswa yang menajdi kelas ekspeerimen dan kelas kontrol, serta membuat Rencana Pelaksanaan Pembelajaran (RPP) teknik takalintardan instrumen-instrumen yang digunakan ketika penelitian. Kedua, pelaksanaan penelitian, dimana pelaksanaan penelitian ini dilakukan dengan penempatan sampel pada kelompok eksperimen dan kelompok kontrol, mengatur kondisi perlakuan terhadap kelompok eksperimen bukan kepada kelompok kontrol, dan melakukan perlakuan atau treatment pelaksanaan teknik takalintarterhadap kelompok eksperimen, dan pembelajaran konvensional terhadap kelompok kontrol, serta masing-masing kelompok diberi posttes sesuai dengan variabel dependent. Ketiga, pengumpulan data dan analisis data yang telah diperoleh. Keempat, membuat laporan penelitian.

\section{Hasil dan Pembahasan}

Hasil uji-t perbedaan rerata posttes kemampuan proses kognitif siswa yaitu bahwa nilai signifikansi (P-value) untuk faktor pembelajaran sebesar $0,000<0,05$ maka $\mathrm{H}_{0}$ ditolak. Dengan kata lain, terdapat perbedaan rerata skor posttes kemampuan proses kognitifsiswa antara kelompok kontrol dengan kelompok eksperimen. Adapun hasil perhitungan uji perbedaan rerata dapat dilihat pada tabel 1 berikut ini.
Tabel 1

Hasil Pengujian Perbedaan Kemampuan Proses Kognitif Siswa

\begin{tabular}{ccccc}
\hline Pembelajaran & Perbedaan & Df & Sig. & $\mathrm{H}_{0}$ \\
\hline Eksperimen- & $8,52>$ & 38 & 0,000 & Ditolak \\
Kontrol & 6,88 & & &
\end{tabular}

Jika dilihat dari Tabel 1 di atas, hasil rata-rata skor posttes kelompok eksperimen adalah 8,52 dan kelompok kontrol adalah 6,88. Dengan memperhatikan rata-rata skor posttes antara kelompok eksperimen dan kelompok kontrol dapat disimpulkan bahwa kemampuan proses kognitifsiswa kelompok eksperimen lebih baik daripada kelompok kontrol secara signifikan. Rerata skor posttes siswa kelompok eksperimen $(8,52)$ dan kelompok kontrol $(6,88)$ berbeda sebesar 1,64. Hal tersebut memberikan asumsi bahwa kualitas peningkatan kemampuan proses kognitifsiswa kelompok eksperimen lebih baik.

Hasil Uji signifikansi terhadap perbedaan rerata skor postes kelompok eksperimen dengan rerata skor postes kelompok kontrol diperoleh bahwa, dalam tingkat keberartian $\alpha=0,05$ secara meyakinkan terdapat perbedaan yang signifikan antara rerata skor postes kelompok eksperimen dengan rerata skor posttes kelompok kontrol. Peningkatan rerata hasil kemampuan proses kognitif siswa kelas ekperimen lebih besar daripada rerata hasil kemampuan proses kognitif siswa kelompok kontrol, sehingga dapat diketahui bahwa teknik takalintarlebih berpengaruh secara 
signifikan daripada pembelajaran kemampuan proses kognitif siswa sekolah dasar pada konsep perkalian.

Dalam penelitian ini dapat dilihat seberapa besar pengaruh teknik takalintar terhadap kemampuan proses kognitifsiswa pada konsep perkalian. Rumus yang digunakan untuk mengetahui besar pengaruh (Effect Size) dengan rumus Cohen's. Pada penelitian ini telah diketahui bahwa hasil perhitungan effect size dengan menggunakan bantuan program Effect Size (Cohen's d) Calculator For a Students t-Test oleh Dr. Daniel Soper, dengan cara memasukkan nilai pada Calculator For a Students mean kelas eksperimen, mean kelas kontrol, standard deviation eksperimen dan standard deviation kontrol diperoleh nilai sebesar 0,892 .

Nilai effect size sebesar 0,892, jika diinterpretasikan ke tingkatan pengaruh termasuk dalam tingkatan pengaruh yang tinggi. Sehingga dapat disimpulkan bahwa teknik takalintar memberikan pengaruh tinggi terhadap kemampuan proses kognitif siswa pada konsep perkalian.

Hasil penelitian yang menunjukkan terdapat pengaruh teknik takalintar terhadap kemampuan proses kognitif siswa pada konsep perkalian di sekolah dasar. Pada umumnya, guru mengajarkan konsep perkalian menggunakan teknik bersusun panjang dan teknik bersusun pendek. Akan tetapi, pada penelitian ini pembelajaran perkalian menggunakan teknik takalintar. Teknik takalintar yang digunakan yaitu pengembangan dari media batang napieryang merupakan alat perhitungan untuk menyederhanakan tugas berat dalam perkalian (Sobel, et.al., 2002: 108).

Pembelajaran mengenai konsep perkalian dipandang efektif manakala dibelajarkan kepada siswa sekolah dasar supaya prestasi belajar siswa meningkat secara optimal. Hal ini senada dengan hasil penelitian Fauziah (2017) yang menunjukkan bahwa penggunaan metode Team Games Tournament (TGT) dengan Media Tabel Perkalian Pintar (TAKALINTAR) efektif terhadap pencapaian prestasi belajar Matematika Kelas III SDN Prawit 1 materi pokok perkalian Tahun Pelajaran 2016/2017.

Hasil penelitian Fauziah (2017) mengenai efektivitas teknik takalintar terhadap prestasi belajar siswa mengenai konsep perkalian ini memperkuat argumen yang menjelaskan bahawa teknik takalintar ini sangatlah baik manakala diterapkan pada pembelajaran perkalian di sekolah dasar. Selain itu, hasil penelitian serupa yang dilaksanakan Hutami, Amir \& Hadiyah (2013) yang menunjukkan bahwa kemampuan menghitung siswa yang menggunakan media batang napier lebih baik dibandingkan tanpa media (perkalian bersusun).

Kemampuan siswa dalam menghitung perkalian dibuktikan lebih baik menggunakan teknik takalintar yang merupakan pengembangan dari media batang napier daripada penggunaan teknik bersusun. Selain itu, Waqi'ah (2016) juga 
mengadakan penelitian yang

menghasilkan bahwa pembelajaran menggunakan alat peraga batang napier dapat meningkatkan aktivitas belajar siswa dan hasil belajar matematika siswa kelas III SDN Tampungrejo Puri Kabupaten Mojokerto. Hal ini membuktikan bahwa selain kemampuan siswa, aktivitas, hasil belajar dan prestasi siswa yang menggunakan teknik takalintar lebih baik daripada siswa yang menggunakan teknik bersusun.

Oleh karena itu, kemampuan proses kognitif siswa pun akan lebih meningkat menggunakan teknik takalintar dibandingkan dengan penggunan teknik bersusun yang seering guru terapkan pada pembelajaran perkalian. Sehingga teknik takalintar ini merupakan salah satu inovasi yang dapat guru laksanakan dalam pembelajaran perkalian.

Selain efektif dalam pembelajaran perkalian untuk siswa sekolah dasar, penggunaan teknik takalintar juga efektif dalam meningkatkan kemampuan siswa berhitung perkalian untuk anak berkebutuhan khusus. Hal ini dibuktikan berdasarkan hasil penelitian Aristiani (2013) bahwa penggunaan media batang napier dalam meningkatkan kemampuan operasi perkalian bagi anak kesulitan belajar kelas 3 SD 11 Belakang Tangsi Padang.

Berdasarkan hasil penelitian beberapa peneliti yang menunjukkan bahwa media batang napier yang dikembangkan melalui teknik takalintar efektif adalam mengembangkan kemampuan berhitung, 452 aktivitas, hasil belajar dan prestasi belajar siswa. Selain itu, kemampuan proses kognitif siswapun berkembang dengan baik, dimana kemampuan proses kognitif merupakan kemampuan siswa dalam melakukan proses kegiatan berpikir dan bernalar dalam memecahkan suatu masalah. Proses kognitif terdapat pada dimensi pengetahuan yang terdiri dari konsep dan pemahaman (Anderson \& Krathwohl, 2001).

Guru perlu memahami kondisi kognitif dari siswa dan mengatur tingkat proses belajar karena setiap siswa akan melalui proses-proses kognitif (Sari, dkk,2018). Hal ini dikarenakan kemampuan proses kognitif adalah salah satu ranah yang menjadi penilaian terpenting dalam proses pembelajaran. Kemampuan kognitif terdiri dari enam tahapan yaitu ingatan, pemahaman, penerapan, analisis, evaluasi dan menciptakan. Hal ini mencakup kemampuan siswa dalam memahami suatu hal atau materi pembelajaran (Rosa, 2017).

Kemampuan proses kognitif sangatlah perlu dikembangkan pada saat siswa belajar. Hal ini senada dengan pendapat Ausubel (Dahar, 2011) bahwa belajar dapat diklasifikasikan dalam dua dimensi. Dimensi pertama berhubungan dengan cara informasi atau konsep pelajaran yang disajikan pada siswa melalui penerimaan atau penemuan. Sedangkan dimensi kedua, menyangkut cara bagaimana siswa dapat mengaitkan informasi itu pada struktur kognitif yang telah ada. Struktur kognitif ialah fakta, konsep, dan 
generalisasi yang telah dipelajari dan diingat oleh siswa.

Oleh karena itu, pada saat siswa belajar matematika, alangkah lebih baiknya manakala guru mampu menstimulus kemampuan proses kognitif siswa supaya pembelajaran dapat berjalan efektif sesuai dengan yang diamanatkan tujuan pendidikan nasional. Salah satu upaya yang dapat dilakukan guru yaitu dengan melaksanakan pembelajaran matematika melalui teknik takalintar pada konsep perkalian di sekolah dasar.

Berikut beberapa penelitian lain beserta topik yang diteliti dengan memperhatikan kemampuan proses kognitif siswa SD agar mencapai pembelajaran yang efektif, yaitu: Konsep Sifat Komutatif dan Asosiatif pada Bilangan Bulat (2012); Konsep Nilai Tempat (Matitaputy, 2016); Pecahan (Wardana \& Damayani, 2017; Afriansyah, 2017); Persentase (Sarumaha, 2018); dan Operasi Hitung pada Bilangan (Suwarto, 2018).

\section{Kesimpulan}

Berdasarkan pengolahan data, hasil analisis serta pembahasan, maka penelitian ini dapat disimpulkan bahwa kemampuan proses kognitif siswa mengenai materi perkalian yang diajarkan dengan menggunakan teknik takalintar lebih tinggi daripada siswa yang diajarkan tanpa menggunakan teknik takalintar. Hal ini dapat dilihat dari hasil uji-t diperoleh nilai signifikansi $<0,05(0,000<0,05)$ maka $\mathrm{H}_{\mathrm{o}}$ ditolak, dengan demikian rataratakemampuan proses kognitifsiswa kelas

\section{Mosharafa: Jumal Pendidikan Matematika}

eksperimen lebih besar dari kemampuan proses kognitifsiswa kelas kontrol. Hal ini juga dibuktikan melalui hasil perhitungan effect size dengan menggunakan bantuan program Effect Size (Cohen's d) Calculator For a Students t-Test oleh Dr. Daniel Soper, diperoleh nilai sebesar 0,892. Nilai effect size ini termasuk dalam tingkatan pengaruh yang tinggi. Sehingga dapat disimpulkan bahwa teknik takalintar memberikan pengaruh tinggi terhadap kemampuan proses kognitifpada konsep perkalian.

\section{Daftar Pustaka}

Afriansyah, E. A. (2012). Implementasi PMRI dalam Materi Sifat Komutatif dan Asosiatif pada Bilangan Bulat untuk Level Siswa SD/MI. Mosharafa: Jurnal Pendidikan Matematika, 1(2), 67-72.

Afriansyah, E. A. (2017). Desain Lintasan Pembelajaran Pecahan melalui Pendekatan Realistic Mathematics Education. Mosharafa: Jurnal Pendidikan Matematika, 6(3), 463474.

Anderson, L.W. \& Krathwohl, D. A.(2001). A Taxonomy for Learning, Teaching, and Assessing. New York: Longman.

Aristiani, N. (2013). Penggunaan Media Batang Napier dalam Meningkatkan Kemampuan Operasi Perkalian Bagi Anak Kesulitan Belajar Kelas 3 SD 11 Belakang Tangsi Padang. Jurnal Ilmiah Pendidikan Khusus, 1(1), 294310.

Dahar, R. W. (2011). Teori-teori Belajar dan Pembelajaran. Jakarta: Erlangga. 
Fauziah, U. (2018). Efektivitas Penggunaan Metode Pembelajaran Teams Games Tournaments (TGT) dengan Media Tabel Perkalian Pintar (Takalintar) Terhadap Pencapaian Prestasi Belajar Matematika Kelas III Sdn Prawit 1. Jurnal Mahasiswa Unsri, 2(2), Hal 1-17.

Fraenkel, J. R. \& Wallen, N. E. (2007). How to Design and Evaluate Research in Education. New York: Mcgraw hill.

Hutami, Y, F., Amir \& Hadiyah. (2013). Pengaruh Penggunaan Media Batang Napier Terhadap Kemampuan Menghitung Perkalian Bilangan Cacah Siswa Kelas IV SD Se-Gugus Pangeran Diponegoro Wonosobo Tahun 2012. Jurnal Didaktika Dwija Indria (Solo), 3(1), 1-6.

Matitaputy, C. (2016). Miskonsepsi Siswa dalam Memahami Konsep Nilai Tempat Bilangan Dua Angka. Mosharafa: Jurnal Pendidikan Matematika, 5(2), 113-119.

Rosa, F. C. (2017). Eksplorasi Kemampuan Kognitif Siswa Terhadap Kemampuan Memprediksi, Mengobservasi dan Menjelaskan Ditinjau Dari Gender. JPF Jurnal Pendidikan Fisikan universitas Muhammadiyah Metro, 5(2), 111-118.

Sari, Y. P., Amilda, \& Syutaridho. (2018). Identifikasi Kemampuan Kognitif Siswa Dalam Menyelesaikan SoalSoal Materi Bangun Ruang Sisi Datar. Jurnal Radenfatah, 1(2), 144-164.

Sarumaha, Y. A., Putri, R. I. I., \& Hartono, Y. (2018). Percentage Bar: A Model for Helping Fifth Grade Students Understand Percentages. Mosharafa: Jurnal Pendidikan Matematika, 7(2), 155-166.
Sobel, Max A., Evan M. \& Maletsky. (2002). Mengajar Matematika: Sebuah Buku Sumber Alat Peraga, Aktivitas, dan Strategi Edisi Ketiga. Jakarta: Erlangga.

Suwarto. (2018). Analisis Kesulitan Belajar Operasi Hitung pada Siswa Kelas Satu Sekolah Dasar. Mosharafa: Jurnal Pendidikan Matematika, 7(2), 285-294.

Waqi'ah, N. (2016). Upaya Meningkatkan Hasil Belajar Matematika dengan Alat Peraga Batang Napier. BRILIANT: Jurnal Riset dan Konseptual, 1(1), 7481.

Wardana, M. Y. S. \& Damayani, A. T. (2017). Persepsi Siswa terhadap Pembelajaran Pecahan di Sekolah Dasar. Mosharafa: Jurnal Pendidikan Matematika, 6(3), 451-462. 